ЗАДОВОЛЕНІСТЬ СТУДЕНТІВ МЕДИЧНОГО КОЛЕДЖУ НАВЧАЛЬНИМ ПРОЦЕСОМ В УМОВАХ ДИСТАНЦИЙНОГО НАВЧАННЯ ПІД ЧАС ПАНДЕМІЇ COVID-19

\title{
SATISFACTION OF MEDICAL COLLEGE STUDENTS WITH THE EDUCATIONAL PROCESS IN THE CONDITIONS OF DISTANCE LEARNING DURING THE COVID-19 PANDEMIC
}

УДК 159.923:377.018.43-057.87 DOI https://doi.org/10.32843/26635208.2021.25.21

\section{Ткаченко О.А.}

к.психол.н.

доцент кафедри загальної

та вікової психології

Криворізький державний педагогічний університет

\section{Чичинська О.В.}

психолог

КЗ «Криворізький фраховий медичний коледж»

Дніпропетровської обласної ради»

\section{Письменна О.М.}

викладач

КЗ «Криворізький фраховий

медичний коледж»

Дніпропетровської обласної ради»
Стаття присвячена аналізу френомену задоволеності як показника якості освіти й емпіричному дослідженню задоволеності студентів медичного коледжу навчальним процесом в умовах дистаниійного навчання у зв'язку з пандемією COVID-19.

у статті розкрито психологічний зміст задоволеності як позитивно забарвленого емоційного стану людини, що наступає від досягнення бажаного результату, залежить від потреб, вимог, сподівань, очікувань людини, їі можливостей щодо їх реалізації. Зазначено, що задоволеність, зокрема задоволеність студентів навчальним процесом, характиризується суб'єктивністю, мінливістю, водночас має істотний мотиваційний потенціал до навчальної діяльності. Через останнє задоволеність студентів навчальним процесом науковці розглядають як основний показник якості надання освітніх послуг. Авторами було описано та cucmeматизовано основні чинники задоволеності студентів навчальним процесом. Створення відповідних умов навчання розглянуто як критерії задоволеності навчальним процесом, а показниками виступали думки студентів про відповідність цих умов їхнім потребам, вимогам, очікуванням, сподіванням. У статті представлено розроблену авторами методику анкетування студентів щодо їхньої задоволеності навчальним процесом. Висвітлено результати емпіричного дослідження основних елементів задоволеності студентів медичного коледжу навчальним процесом, який відбувався в умовах дистанційного навчання у звязку з пандемією COVID-19, результати порівняльного аналізу отриманих даних із відповідними даними, отриманими в аналогічному дослідженні минулого року. Констатовано, що частковий перехід на дистаниійні фрорми навчання істотно не вплинув на задоволеність студентів медичного коледжу навчальним процесом майже за всіма показниками, за винятком незадоволеності збільшенням навчального навантаження та рівнем компетентності окремих викладачів. Наголошено на необхідності розроблення психолого-педагогічних заходів щодо збільшення арсеналу методів та прийомів дистанційного навчання, їх упровадження у професійну діяльність викладачів.

Ключові слова: задоволеність, задоволеність навчальним процесом, елементи, фрактори, критерії, показники задоволеності навчальним прочесом.
The article is devoted to the analysis of the phenomenon of satisfaction as an indicator of the quality of education and the empirical research of the satisfaction of medical college students with the educational process in the conditions of distance learning in connection with the COVID-19 pandemic.

The article reveals the psychological meaning of satisfaction as a positively colored emotional state of a person, which comes from achieving the desired result, depends on the needs, requirements, hopes, expectations of human, his ability to implement them. It is noted that satisfaction, in particular student satisfaction with the educational process, is characterized by subjectivity, variability and, at the same time, has a significant motivational potential for educational activities. Scientists consider students satisfaction with the educational process as the main indicator of the quality of educational services. The authors described and systematized the main factors of student satisfaction with the educational process. The creation of appropriate learning conditions was considered as a criterion for satisfaction with the educational process, and the indicators were the testimonies of students about the compliance of these conditions with their needs, requirements, hopes, expectations. The article presents the method of questionnaires developed by the authors on students satisfaction with the educational process. The results of an empirical researh of the main elements of medical college students satisfaction with the learning process, which took place in the context of distance learning in connection with the COVID-19 pandemic, the results of comparative analysis of data with relevant data obtained in a similar research that was in the last year.

It was found that the partial transition to distance learning did not significantly affect the satisfaction of medical college students with the educational process in almost all indicators, except for dissatisfaction with the increase in workload and the level of competence of individual teachers. The authors of the article established the need to develop psychological and pedagogical measures to increase the arsenal of methods and techniques of distance learning, and their implementation in the professional activities of teachers.

Key words: satisfaction, satisfaction with educational process, elements, factors, criteria, indicators of satisfaction with educational process.
Система освіти, зокрема вищої, не може розвиватись без урахування запиту українського суспільства. А запит цей передусім стосується якості освіти. Посилаючись на думку закордонних експертів, вітчизняні фахівці стверджують, що тотальна і незворотна «масовізація» вищої освіти завжди перебуває в оберненій залежності від якості вищої освіти, особливо якщо ріст кількості закладів вищої освіти (далі - ЗВО) відбувається на тлі скорочення кількості здобувачів вищої освіти [4, с. 11-12]. Продовження реформи серед- 
ньої освіти, зниження фінансової стабільності українців, можливість вступу до європейських ЗВО сприятиме подальшому зменшенню кількості здобувачів вищої освіти, що збільшить конкуренцію серед ЗВО. Тому ЗВО активно створюють та розвивають свою систему оцінку якості освітніх послуг. Дієвим інструментом такої системи $є$ опитування студентів. Основним принципом оцінки якості освітніх послуг $є$ орієнтація на рівень задоволеності студентів різними складовими частинами процесу надання цих послуг [7], інакше кажучи, орієнтація на рівень задоволеності навчальним процесом.

Ставлення до навчального процесу як до управління навчально-виховною діяльністю, безпосередньо умовами навчання, дозволяе бачити можливість покращення його якості через розвиток нових форм його здійснення. Особливе місце серед них в останні роки відводилось дистанційному навчанню. Пандемія COVID-19 стрімко змінила підходи до організації освітнього процесу у ЗВО, значно прискорила впровадження дистанційного навчання. Виникла необхідність наукового переосмислення принципів оцінки якості освітніх послуг і моніторингу процесу навчання, яке відбувається в нових умовах.

Мета статті полягає в теоретичному аналізі феномену задоволеності як показника якості освіти й емпіричному дослідженні задоволеності студентів медичного коледжу навчальним процесом в умовах дистанційного навчання у зв'язку з пандемією COVID-19.

В українських та закордонних дослідженнях М. Боришевського, В. Гензи, Л. Дикої, Є. Ільїна, Л. Кулікова, С. Максименка, І. Чеснокової та інших різнобічно представлено вивчення стану задоволеності в межах розгляду емоційних станів людини. У психології задоволеність прийнято визначати як емоційний стан людини, що наступає в разі досягнення бажаного результату в діяльності і спілкуванні.

Задоволеність прямо залежить від характеру потреб, їхньої глибини. Але задоволеність залежить також і від реальних можливостей, що дозволяють реалізувати ці потреби на практиці [6]. Споріднений термін «задовольняти» загалом тлумачиться як «бути відповідним до чиїхось вимог, сподівань» [9]. Близькими за значеннями поняттями до терміна «задоволення» $€$ «приємність», «задоволення потреби», «захоплення», «щастя», а до «незадоволення» - «дисгармонія», «фрустрація», «розчарування» та «дисонанс» [12].

У класичній психології задоволенням називається емоційний стан, який характеризується приємністю і який зумовлює поведінку 3 ранніх років. 3. Фройд уважав принцип задоволення головною спонукальною силою людської поведінки. Сучасні вчені появу задо- волення розуміють як динамічний процес, у якому оцінка досвіду з погляду задоволення надається в межах від небажаного незадоволення до бажаного задоволення. Задоволення - це відносний стан, а не абсолютний і незмінний [13].

За А. Маслоу, задоволеність - позитивно забарвлена емоція, що супроводжує задоволення потреб [3]. Між задоволеністю і діяльністю існує складний взаємозв'язок: з одного боку, задоволеність - емоція, яка виникає як наслідок виконання діяльності, що привела до задоволення потреб, з іншого - ця емоція має велику спонукальну силу до діяльності.

Розглядаючи навчання як вид діяльності, О. Васильєва з колегами задоволеність навчанням визначає як відображення відповідності умов навчально-освітнього процесу навчального закладу вимогам студента $[1 ; 2]$. Яких же умов вимагають студенти? Знайти відповідь на це питання дослідники намагались шляхом визначення чинників, які впливають на задоволеність навчальним процесом. Результати порівняльного аналізу різних підходів до визначення зазначених чинників представлено в таблиці 1.

В О. Васильєвої та її співробітників задоволеність навчанням розкрито через аналіз трьох елементів, між якими існують міцні зв'язки: задоволеність соціальним статусом, задоволеність спеціальністю, яку опановує індивід, і задоволеність функціональним наповненням навчально-освітнього процесу як ступінь адаптаціїдопевного навчального середовища $[1 ; 2]$.

Сучасна тенденція поширення розуміння навчання як процесу надання освітніх послуг дозволяє задоволення студентом цим процесом розглядати як задоволення послугою. Теоретичний аналіз задоволенності споживача, проведений О. Щербою [8], дозволив констатувати, що поширеною серед науковців (Дж. Александр, Ф. Котлер, Б. Марціняк, Н. Хілл) є думка про тісний зв'язок між задоволеністю послугою й очікуваннями споживача щодо неї, важливістю її різних властивостей, рівнем його вимог та рівнем пропозиції, тобто рівнем надання послуги, суб'єктивним досвідом їі отримання. Отримані науковцем результати також довели, що задоволеність послугою $€$ важливим чинником подальшої поведінки споживача щодо організації, що надала цю послугу.

За результатами узагальнення даних, отриманихпід час проведення теоретичного аналізу факторів задоволеності студентів навчальним процесом (див. табл. 1), було розроблено відповідну анкету для опитування студентів Криворізького медичного коледжу (далі - КМК). Анкета включала низку запитань, спрямованих на дослідження всіх елементів задоволеності навчальним процесом. Створення умов забез- 
печення навчального процесу, що відповідають потребам студентів, виступало критерієм їхньої задоволеності останнім.

В анкетуванні, яке було проведене у травні 2021 р., взяли участь 60 здобувачів освіти ступенів молодшого спеціаліста та бакалавра. Учасники анкетування - студенти, які навчаються за спеціальностями: «Сестринська справа», «Лікувальна справа», «Медико-про- філактична справа», «Лікувальна діагностика», «Фармація». Варто зазначити, що в березні квітні 2020 р. було проведено моніторинг задоволеності випускників КМК 2019/2020 н. р. як споживачів освітніх послуг, що були надані коледжем. До цього опитування було залучено 56 осіб. Результати дослідження представлено на сайті КМК (http://kmk.in.ua/images/ psihologicnaslyjba/7.pdf). Маємо зауважити,

Фактори задоволеності студентів навчальним процесом (далі - ФЗСНП)

\begin{tabular}{|c|c|c|c|}
\hline $\begin{array}{c}\text { Елементи } \\
\text { задоволеності } \\
\text { навчальним процесом } \\
\text { за О. Васильєвою } \\
\end{array}$ & $\begin{array}{c}\text { ФзСНП } \\
\text { за К. Елліот та } \\
\text { М. Хілі [11] }\end{array}$ & $\begin{array}{c}\text { ФЗСНП } \\
\text { за Л. Дюком та } \\
\text { Дж. Віксом [10] }\end{array}$ & $\begin{array}{c}\text { ФзСНП } \\
\text { за М. Сидоровим та } \\
\text { В. Довбнею [5] }\end{array}$ \\
\hline $\begin{array}{l}\text { Задоволеність } \\
\text { спеціальністю }\end{array}$ & $\begin{array}{c}\text { Підготовка до } \\
\text { майбутньої кар єри або } \\
\text { аспірантури } \\
\end{array}$ & & $\begin{array}{l}\text { Намір працювати за } \\
\text { спеціальністю }\end{array}$ \\
\hline $\begin{array}{c}\text { Задоволеність } \\
\text { соціальним статусом }\end{array}$ & Розмір класу & $\begin{array}{l}\text { Залученість } \\
\text { студентів до } \\
\text { навчального } \\
\text { процесу } \\
\end{array}$ & $\begin{array}{c}\text { Психологічний клімат у групі, } \\
\text { рівень взаємопідтримки між } \\
\text { одногрупниками, стосунки між } \\
\text { одногрупниками } \\
\end{array}$ \\
\hline \multirow{6}{*}{$\begin{array}{c}\text { Задоволеність } \\
\text { функціональним } \\
\text { наповненням навчально- } \\
\text { освітнього процесу }\end{array}$} & Якість навчання & Якість освіти & \\
\hline & $\begin{array}{l}\text { Зміст та різноманітність } \\
\text { курсів, класифікація на } \\
\text { основних курсах } \\
\end{array}$ & & $\begin{array}{c}\text { Зміст навчальних предметів, } \\
\text { їх цікавість, складність, } \\
\text { корисність }\end{array}$ \\
\hline & \multirow[t]{2}{*}{$\begin{array}{c}\text { Наявність фахівців, } \\
\text { зокрема факультативних }\end{array}$} & \multirow[t]{2}{*}{ Ресурси } & $\begin{array}{c}\text { Кваліфікація викладачів, } \\
\text { зрозумілість викладання, } \\
\text { взаєморозуміння } \\
\text { з викладачами } \\
\end{array}$ \\
\hline & & & $\begin{array}{c}\text { Достатність та сучасність } \\
\text { техобладнання }\end{array}$ \\
\hline & & & $\begin{array}{c}\text { Динамічність розкладу, } \\
\text { наявність «вікон» у розкладі }\end{array}$ \\
\hline & $\begin{array}{c}\text { Академічний, } \\
\text { практичний, загальний } \\
\text { досвід }\end{array}$ & $\begin{array}{l}\text { Результати } \\
\text { навчання }\end{array}$ & \\
\hline
\end{tabular}

Таблиця 2

Задоволеність спеціальністю

\begin{tabular}{|c|c|c|}
\hline \multirow{2}{*}{$\begin{array}{c}\text { Варіанти відповідей, } \\
\text { що ілюструють ступінь } \\
\text { задоволеності навчальним } \\
\text { процесом }\end{array}$} & \multicolumn{2}{|c|}{ Кількість студентів, \% } \\
\hline & 2019/2020 н. p. & 2020/2021 н. p. \\
\hline \multicolumn{3}{|c|}{ Чи задоволені тим, що навчаєтесь за обраною спеціальністю? } \\
\hline Задоволений & 66,1 & 73,3 \\
\hline Частково задоволений & 33,9 & 26,7 \\
\hline Незадоволений & - & - \\
\hline \multicolumn{3}{|c|}{ Можна стверджувати, що Ви розчарувались в обраній спеціальності під час навчання? } \\
\hline Так & 3,6 & 1,7 \\
\hline $\mathrm{Hi}$ & 96,4 & 98,3 \\
\hline \multicolumn{3}{|c|}{ Ви бачите перспективи працевлаштування за обраною спеціальністю? } \\
\hline Так & 80,4 & 93,3 \\
\hline $\mathrm{Hi}$ & 19,6 & 6,7 \\
\hline \multicolumn{3}{|c|}{$\begin{array}{c}\text { Чи плануєте Ви продовжувати навчання і підвищувати кваліфікаційний рівень за обраною } \\
\text { спеціальністю? }\end{array}$} \\
\hline Так, планую & 32,2 & 48,3 \\
\hline Нi, не планую & 26,8 & 16,6 \\
\hline Важко відповісти & 37,5 & 35 \\
\hline
\end{tabular}


що прагнення здійснити порівняльний аналіз і простежити динаміку досліджуваного явища вплинуло на добір і формулювання питань створеної нами анкети.

Перед тим, як перейти до представлення результатів анкетування, зазначимо, що основною відмінністю умов здійснення навчального процесу у КМК у 2019/2020 і 2020/2021 н. p.
$€$ значне збільшення обсягу дистанційного навчання у зв'язку з пандемією COVID-19.

Результати емпіричного дослідження задоволеності студентів КМК обраною спеціальністю представлено в таблиці 2. Можемо констатувати, що більшість студентів задоволені обраною спеціальністю, інші частково задоволені, на що вказують показники всіх

Задоволеність соціальним статусом

Таблиця 3

\begin{tabular}{|l|c|c|}
\hline \multirow{2}{*}{$\begin{array}{c}\text { Варіанти відповідей, } \\
\text { що ілюструють ступінь } \\
\text { задоволеності навчальним } \\
\text { процесом }\end{array}$} & $\mathbf{2 0 1 9 / 2 0 2 0}$ н. p. & Кількість студентів, \% \\
\cline { 2 - 3 } & $\mathbf{2 0 2 0 / 2 0 2 1}$ н. p. \\
\hline Чи перешкоджав вплив із боку інших студентів прояву Ваших здібностей під час навчальних занять? \\
\hline Так & 8,9 & 10 \\
\hline $\mathrm{Hi}$ & 91,1 & 90 \\
\hline
\end{tabular}

Задоволеність функціональним наповненням навчально-освітнього процесу

Таблиця 4

Варіанти відповідей, що ілюструють ступінь задоволеності навчальним процесом

Кількість студентів, \% 2019/2020 н. p. 2020/2021 н. p.

Як Ви оцінюєте якість освітніх послуг у КМК?

\begin{tabular}{|l|c|c}
\hline Задоволений повністю & 37,5 & 21,6 \\
\hline Більшою мірою задоволений & 48,2 & 70 \\
\hline Не повною мірою задоволений & 3,6 & 8,3 \\
\hline Незадоволений & - & - \\
\hline
\end{tabular}

Можна стверджувати, що надмірний обсяг навчального навантаження ускладнює Ваше навчання?

\begin{tabular}{|c|c|c|}
\hline Так & 28,6 & 68,8 \\
\hline $\mathrm{Hi}$ & 71,4 & 31,2 \\
\hline \multicolumn{3}{|c|}{ Методи викладання і навчання ефективні для цієї програми? } \\
\hline Безумовно згоден & 26,8 & 30 \\
\hline В основному згоден & 66,1 & 60 \\
\hline Не згоден & 1,8 & 1,6 \\
\hline Важко відповісти & 1,8 & 8,3 \\
\hline \multicolumn{3}{|c|}{ Ви задоволені процесом викладання? } \\
\hline Безумовно задоволений & 28,6 & 31,6 \\
\hline В основному задоволений & 60,7 & 61,6 \\
\hline Незадоволений & 1,8 & - \\
\hline Важко відповісти & 5,4 & 6.6 \\
\hline \multicolumn{3}{|c|}{ Чи має місце некомпетентність окремих викладачів? } \\
\hline Так & 8,9 & 25 \\
\hline $\mathrm{Hi}$ & 91,1 & 75 \\
\hline \multicolumn{3}{|c|}{ Чи задоволені Ви рівнем комп'ютерного забезпечення навчального процесу? } \\
\hline Задоволений повністю & 30,4 & 45 \\
\hline Більшою мірою задоволений & 42,9 & 46,6 \\
\hline Не повною мірою задоволений & 17,9 & 8,3 \\
\hline Незадоволений & - & - \\
\hline \multicolumn{3}{|c|}{ Чи відповідає Вашим потребам забезпечення навчально-методичною літературою? } \\
\hline Так & 91,1 & 88,3 \\
\hline $\mathrm{Hi}$ & 8,9 & 11,7 \\
\hline \multicolumn{3}{|c|}{ Можна стверджувати, що Ваше навчання ускладнене через незручний розклад? } \\
\hline Tак & 14,3 & 20 \\
\hline $\mathrm{Hi}$ & 85,7 & 80 \\
\hline
\end{tabular}


досліджуваних критеріїв. Також констатовано, що в умовах пандемії COVID-19 збільшилась кількість студентів однозначно задоволених обраною спеціальністю, таких, які не розчаровані в ній, бачать перспективи працевлаштування, планують продовжувати навчання і підвищувати кваліфікаційний рівень за цією спеціальністю. Отже, можна зробити припущення, що пандемія COVID-19 спровокувала підвищення престижу медичних працівників в українському та світовому суспільстві, а це, у свою чергу підвищило ступінь задоволеності студентів-медиків обраною спеціальністю.

У таблиці 3 представлено результати дослідження задоволеності студентів КМК соціальним статусом.

Констатація того, що студенти переважно (>90\%) не зазнають перешкод із боку однокурсників щодо прояву своїх здібностей під час навчальних занять, на нашу думку, вказує на їхню задоволеність соціальним статусом, що виявляється в навчальному процесі. Важливо зазначити, що задоволеність соціальним статусом у разі часткового переходу на дистанційне навчання майже не змінилась.

Результати емпіричного дослідження задоволеності студентів КМК наповненням навчально-освітнього процесу представлено в таблиці 4.

Після проведення аналізу результатів анкетування констатуємо деяке зниження задоволеності студентів якістю освітніх послуг. Найбільшу проблему для студентів становить збільшення навчального навантаження. На ускладнення навчання, що пов'язане з надмірним обсягом навчального навантаження наприкінці 2020/2021 н. р. вказали 68,8\% студентів, порівняно із 28,6\% у минулому н.р. у бесідах зі студентами щодо цього після анкетування вдалось з'ясувати, що основна проблема полягає у збільшенні завдань, які потребують розгорнутих письмових відповідей. Відсутність у студентів необхідних навичок призводить до збільшення часу, необхідного на виконання завдань.

Задоволеність процесом викладання збільшилась порівняно 3 минулим навчальним роком. Загалом студенти задоволені методами викладання, хоча збільшилась кількість студентів, які не можуть визначитись щодо цього. Значно збільшилась кількість студентів, які незадоволені компетентністю окремих викладачів. Оскільки педагогічній колектив КМК не зазнав істотних змін у своєму складі, можемо зробити припущення, що зазначена некомпетентність передусім стосується їхньої обізнаності щодо методів, засобів, прийомів саме дистанційного навчання.

Приємно констатувати, що задоволеність студентів рівнем комп'ютерного забезпечення збільшиласявтойчас, колизрослиїхнівідповідні потреби і вимоги до організації зазначеного аспекту забезпечення навчального процесу.

Можемо спостерігати незначне збільшення незадоволеності студентів щодо розкладу. На нашу думку, цей факт можна пояснити об'єктивними причинами. Неможливо здобувати професійну медичну освіту без участі у практичних та лабораторних заняттях, особливо це стосується студентів старших курсів. Прагнення адміністрації коледжу забезпечити студентам таку можливість із дотриманням усіх заходів безпеки в умовах пандемії привело до деяких корекцій у розкладі, зокрема комбінування дистанційних і очних форм навчання. Варто зазначити, що ми прогнозували більший ступінь зростання незадоволеності студентів розкладом. Приємно констатувати, що наші негативні прогнози не підтвердились.

Результати аналізу психологічного змісту задоволеності дозволяють розуміти її як позитивний емоційний стан людини, що наступає від досягнення бажаного результату, залежить від потреб, вимог, сподівань, очікувань людини, її можливостей щодо їх реалізації. З огляду на мотиваційний потенціал задоволеності, зокрема студентів до навчальної діяльності, її використовують як основний показник якості надання освітніх послуг, навіть незважаючи на її суб'єктивність і мінливість. Аналіз чинників задоволеності студентів навчальним процесом дозволив виділити критерії і показники цього явища, розробити та впровадити методику його емпіричного дослідження. Було з'ясовано, що частковий перехід на дистанційні форми навчання істотно не вплинув на задоволеність студентів КМК навчальним процесом майже за всіма показниками, за винятком незадоволеності збільшенням навчального навантаження та рівнем компетентності окремих викладачів. Перспективу подальших розвідок ми бачимо в розробленні психолого-педагогічних рекомендацій щодо збільшення арсеналу методів та прийомів дистанційного навчання, їх упровадженні у професійну діяльність викладачів.

\section{ЛІТЕРАТУРА:}

1. Васильева Е., Плешкунова А., Тагаева Т. Отношение студентов к психолого-педагогической подготовке в медицинском вузе. Стандарты и мониторинг в образовании. 2015. Т. 3. № 4. С. 8-13.

2. Васильева Е., Томилова М., Гайкина М. Вуз в оценке студентов. Оценка условий обучения и качества подготовки : коллективная монография. Lambert Academic Publishing, 2014. 139 c. C. 43.

3. Маслоу А. Психология бытия. Москва : Вести, 1997. $168 \mathrm{c}$

4. Річний звіт Національного агентства із забезпечення якості вищої освіти за 2019 р. / за заг. ред. С. Квіта. Київ : Національне агентство із забезпечення якості вищої освіти, 2020. 244 с. С. 11-12. 
5. Сидоров М., Довбня В. Фактори задоволеності студентів навчальним процесом (на прикладі дослідження студентів КНУ). Соціологічні студії. 2019. № 1 (14). C. 45-52. DOI: 10.29038/2306-39712019-01-45-5.

6. Синявський В., Сергєєнкова О. Психологічний словник. Київ : Науковий світ, 2007. 274 с.

7. Ташкінова О., Гонтар М. Оцінка рівня задоволеності студентів станом навчально-виховного процесу у закладах вищої освіти. Вісник Приазовського державного технічного університеmу / Reporter of the Priazovskyi State Technical University : збірник наукових праць. Маріуполь, 2019. Вип. 3. С. 65-69.

8. Щерба О. Поведінка споживача: вплив післякупівельного задоволення та післякупівельного дисонансу. Габітус. 2020. Вип. 20. С. 20-25. DOI: $10.32843 / 2663-5208.2020 .20 .2$.
9. Яременко В., Сліпушко О. Новий тлумачний словник української мови : у 4-х т. Київ : Аконіт, 1998. T. 1. 1998.910 c. C. 132.

10. Duque L., Weeks J. Towards a model and methodology for assessing student learning outcomes and satisfaction. Quality Assurance in Education. 2010. № 18 (2). C. 84-105. DOI: $10.1108 / 09684881011035321$.

11. Elliot K., Healy M. Key factors influencing student satisfaction related to recruitment and retention. Journal of Marketing for Higher Education. 2001. № 10. P. 1-11. DOI: 10.1300/j050v10n04 01.

12. Kaczmarczyk S. Zastosowanie badań marketingowych. Zarządzanie marketingowe i otoczenie przedsiębiorstwa. Warszawa : PWE, 2006. 379 s.

13. Maison D., Bruin R. Usatysfakcjonować klienta. Marketing w praktyce. 1998. № 5 (21). 